\title{
Performance Evaluation of Tubular Maize Sheller under Frontline Demonstration
}

\author{
Longma Yanger Pongen* and Temjennungsang
}

Krishi Vigyan Kendra, Kohima, Nagaland, India

*Corresponding author: longmakvk@gmail.com (ORCID ID: 0000-0003-4596-9002)

Paper No. 837

Received: $20-12-2019$

Revised: 22-04-2020

Accepted: 26-05-2020

\begin{abstract}
The study was conducted to assess the performance of tubular maize sheller under Frontline Demonstration programme during 2016-2019 under Kohima district of Nagaland. Maize sheller developed by CIAE was compared to farmers practice of bare hand maize shelling using the finger tips and thumb pressing. The demonstrated result revealed that the performance level of tubular maize sheller (31.36 $\mathrm{kg} / \mathrm{hr}$ ) was double that of farmers practice $(13.11 \mathrm{~kg} / \mathrm{hr})$ in a given time which had increased the shelling capacity by $140 \%$. Shelling efficiency under demonstration remain as high as $99.69 \%$. The average cost of operation per quintal in tubular maize sheller was found to be ₹ 171.58 over farmers practice (₹ 423.70) which saved the operation cost of farmers by $60 \%$. The farmers attitude towards the demonstrated tool was also noted and it was observed that $100 \%$ were in agreement that no special training was required for handling the tool, it avoided injury to fingers during use, reduced drudgery and that the tool to be women friendly. It also revealed that majority were in agreement that it saves time and energy (98.66), avoids irritation of eyes, nose mouth during shelling (98\%) followed by convenient to use and operate (97.33\%). It was also suggested that $4 \%$ percent of the farmers were in agreement to the statement that the tool requires modification.

Highlights

( F Frontline demonstration of tubular maize sheller is a mechanism for connecting the technologies of researchers to farmers.

( Availability of tubular maize sheller had reduced drudgery of women farmers'.
\end{abstract}

Keywords: Frontline Demonstration, Drudgery, Maize Sheller, Shelling Efficiency, Shelling capacity

Maize (Zea mays L.) is an important cereal crop for India and world over. It is widely grown in diverse climatic condition. Numerous varieties have evolved over the years, as it is evident from its popularity. India's maize production during 2018-19 was 27.23 million tonnes, which occupied $77.59 \%$ of total cereals production in the country, with maximum production coming from the state of Karnataka, Madhya Pradesh and Bihar respectively (Anonymous 2019). In Kohima district of Nagaland, the productivity of maize during 2018-19 was 1983 $\mathrm{qt} /$ ha (Anonymous 2019 a). Maize is the second largest crop cultivated by the farmers of Kohima district next only to rice. Maize crops are grown under rainfed condition and harvested as they attain maturity. The harvested maize cobs for seed purpose are sundried and stacked above the fireplace in traditional kitchen for smoke drying. Immature maize is eaten as roasted corn, used as feeds for animal and poultry, for preparation of various value added products (Karmakar and Gouraha 2018). Post harvest operation of Maize involves a lot of activities like nailing, tearing, plaming and dehusking which are done by women manually. Shelling of kernels involves different techniques like rubbing the maize cobs against each other, removing the kernels by slow movement of fingers tips from the cobs and also by hand beating technique where maize 
are stuffed inside gunny bags and beaten with wooden sticks to detach the kernel from the cobs, all these operation leads to drudgery of women (Naveenkumar and Rajshekarappa 2012). In present context the availability of women friendly low cost sheller to reducing drudgery and increase work efficiency was the main concept of introducing the tool through frontline demonstration.

\section{MATERIALS AND METHODS}

The mode of study was conducted as action research participatory approach under Frontline Demonstration (FLD) during the period 2016-19. Eleven villages under Tseminyu sub-division of Kohima District, Nagaland were identified for the demonstration based on maize cultivation practices. Farmers' numbering 150 were randomly selected from those small and marginal categories based on their economic status. Tubular Maize Sheller developed by CIAE Bhopal was assessed for its shelling performance whereas, the farmers' practice of maize shelling using fingers tips and thumb pressing was considered as the local check performance. Each farmer participated in maize shelling both by bare hand as well as using tubular maize sheller, a period of rest was maintain between the demonstration. After the completion of the demonstration each individual was asked to share their attitude towards the tool which was assessed by developing a semi-structured interview scheduled, the collected data's were analysed using MS excel and presented by using the following formulas.

Shelling capacity: The capacity of the maize sheller to shell, the weight of maize per hour. It was calculated as:

Shelling capacity $(\mathrm{Kg} / \mathrm{hr})=\frac{\text { Wt. of maize cobs }}{\text { Average time }} \times$ Duration

Shelling efficiency: The shelling grain received from all the selected maize cobs with respect to total grain input. The shelling efficiency was calculated with the following formula:

Shelling efficiency $(\%$ by weight $)=\frac{\text { Work output }}{\text { Work input }} \times 100$

Shelling cost: The shelling cost is the amount spend to shell maize from the cob per hour. It was calculated by using the following formula:
Shelling Cost $(₹ / Q t)=\frac{\text { Wages paid per hour }}{\text { Maize shelled per hour }} \times 100$

\section{RESULTS AND DISCUSSION}

\section{Performance of tubular maize sheller}

The demonstration was conducted to assess the efficiency of tubular maize sheller with respect to farmers' practice (finger tips and thumb) in one hour. Parameters such as shelling capacity, shelling efficiency and labour economic cost were determined from 150 farmers whose age varied between 20 to 59 years (Table 1). Maize shelling operation are performed by holding the maize sheller in one hand and the other hand holding the maize cob is rotated against it, by doing so, the four teeth of the sheller which is internally fixed opposite to each other gets entangled and removes the grain from the $\mathrm{cob}$, this way the process of shelling gets completed (Imtisenla et al. 2019) A comparative presentation (Table 2) on average shelling performance between tubular maize sheller $(31.36 \mathrm{~kg} / \mathrm{hr})$ and farmers practice $(13.11 \mathrm{~kg} / \mathrm{hr})$ revealed that tubular maize sheller extracted more quantity of maize kernel twice as much as the farmers' practice in one hour. The percentage increase in shelling capacity of tubular maize sheller over farmers practice by an average of $140 \%$ indicated that the shelling capacity increased from 92-177\% over the years. Similar, finding were also reported by Pandey et al. (2013) while comparing tubular maize sheller $(25.44 \mathrm{~kg} /$ hr) with that of traditional method of hand shelling (16.83 kg/hr).

In case of Shelling efficiency, cent percent $(100 \%)$ efficiency was found under farmers' practice while in case of tubular maize sheller it was observed to be $99.69 \%$ on average basis (Singh et al. 2010). The average Cost of operation (Table 3) per quintal of tubular maize shelling and farmers' practice of bare hand shelling was calculated to be Rs.171.58 and Rs. 423.70 respectively. Shelling cost under farmers' practice was found to be higher due to slow and laborious process requiring more labour as compared to shelling by using tubular maize sheller. It was also observed that the average percentage of shelling cost saved per quintal by using tubular maize sheller was about $60 \%$ over the farmers' practice. The percentage of shelling cost 
saved during the demonstrated period of 2016-17, 2017-18 and 2018-19 were $63.84,63.24$ and $47.80 \%$ respectively. The findings are in agreement with that of Chilur et al. (2013) that the cost of bare hand shelling to be higher. Therefore, the finding from the present study can be positively stated that, tubular maize sheller may be horizontally disseminated on a larger scale, as a low cost drudgery reduction tool for small and marginal farmers of the district.

Table 1: Beneficiaries based on years

\begin{tabular}{lllll}
\hline $\begin{array}{l}\text { S1. } \\
\text { No. }\end{array}$ & Year & $\begin{array}{l}\text { Beneficiaries } \\
\text { (Nos) }\end{array}$ & $\begin{array}{l}\text { Age } \\
\text { (Years) }\end{array}$ & $\begin{array}{l}\text { Villages } \\
\text { covered } \\
\text { (Nos) }\end{array}$ \\
\hline 1 & $2016-2017$ & 50 & $35-59$ & 3 \\
2 & $2017-2018$ & 50 & $18-48$ & 4 \\
3 & $2018-2019$ & 50 & $20-56$ & 4 \\
\hline Total & & $\mathbf{1 5 0}$ & $\mathbf{1 1}$ \\
\hline
\end{tabular}

Table 2: Performance parameter of Tubular Maize Sheller to Farmers Practice

\begin{tabular}{|c|c|c|c|c|c|c|}
\hline \multirow[b]{2}{*}{ Year } & \multirow{2}{*}{$\begin{array}{l}\text { Time } \\
\text { (min) }\end{array}$} & \multicolumn{2}{|c|}{$\begin{array}{l}\text { Shelling } \\
\text { capacity } \\
(\mathrm{Kg} / \mathrm{hr})\end{array}$} & \multirow{2}{*}{$\begin{array}{l}\text { Percentage } \\
\text { increase } \\
\text { in shelling } \\
\text { capacity } \\
(\%)\end{array}$} & \multicolumn{2}{|c|}{$\begin{array}{c}\text { Shelling } \\
\text { efficiency } \\
(\%)\end{array}$} \\
\hline & & 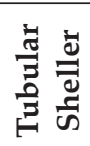 & 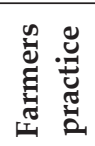 & & 禀 & 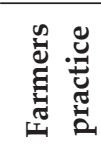 \\
\hline 2016-2017 & 60 & 29.32 & 10.60 & 177 & 99.45 & 100.00 \\
\hline 2017-2018 & 60 & 33.52 & 12.32 & 172 & 99.88 & 100.00 \\
\hline 2018-2019 & 60 & 31.42 & 16.40 & 92 & 99.74 & 100.00 \\
\hline Average & 60 & 31.36 & 13.11 & 140 & 99.69 & 100.00 \\
\hline
\end{tabular}

Table 3: Cost of operation for shelling Performance

\begin{tabular}{|c|c|c|c|c|}
\hline \multirow[t]{2}{*}{ Year } & \multirow{2}{*}{$\begin{array}{c}\text { *Wages/ } \\
\text { hd/day of } \\
8 \text { hrs. } \\
\text { (₹) }\end{array}$} & \multicolumn{2}{|c|}{$\begin{array}{l}\text { Shelling cost } \\
\text { (₹ per quintal) }\end{array}$} & \multirow{2}{*}{$\begin{array}{c}\text { Percentage } \\
\text { Shelling cos } \\
\text { saved } \\
(\%)\end{array}$} \\
\hline & & $\begin{array}{l}\text { Tubular } \\
\text { Sheller }\end{array}$ & $\begin{array}{r}\text { Farmers } \\
\text { practice }\end{array}$ & \\
\hline 2016-2017 & 430 & 183.32 & 507.07 & 63.84 \\
\hline $2017-2018$ & 430 & 160.35 & 436.28 & 63.24 \\
\hline 2018-2019 & 430 & 171.07 & 327.74 & 47.80 \\
\hline Average & 430 & 171.58 & 423.70 & 59.50 \\
\hline
\end{tabular}

*wage calculated as per prevailing rate.

\section{Farmers' attitude towards maize sheller}

A simple attitude questionnaire was prepared and presented to the farmers after the demonstration was over, and were ask to describe their agreement or disagreement towards the tubular maize sheller. Data collected (Table 4) revealed that 100 percent of the respondent were in agreement with four prepared statement that no special training required for handling the tubular maize sheller (150 Nos), avoided injury to fingers during use (150 Nos), it reduces drudgery (150 Nos) and the tool to be women friendly (150 nos). Majority of the farmers were also in agreement with the statement that it saves time and energy (98.66\%), It avoids irritation of eyes, nose, mouth during shelling (98\%), convenient to use and operate $(97.33 \%)$. It was also observed that a negligible percentage $(4 \%)$ of the farmers were in agreement to the statement if the tool required modification or standardization, and it could be due to the fact that most of the local

Table 4: Farmers attitude towards tubular maize sheller (N=150)

\begin{tabular}{|c|c|c|c|c|c|}
\hline & & & & ponse & \\
\hline & Statemonts & & gree & & agree \\
\hline & Statements & $\begin{array}{l}\text { Frequency } \\
\text { (Nos) }\end{array}$ & $\begin{array}{l}\text { Percentage } \\
(\%)\end{array}$ & $\begin{array}{l}\text { Frequency } \\
\text { (Nos) }\end{array}$ & $\begin{array}{l}\text { Percentage } \\
(\%)\end{array}$ \\
\hline 1 & $\begin{array}{l}\text { No special training required for handling the } \\
\text { tubular maize sheller }\end{array}$ & 150 & 100 & 00 & 0.00 \\
\hline 4 & $\begin{array}{l}\text { It avoids irritation of eyes, nose, mouth during } \\
\text { shelling }\end{array}$ & 147 & 98.00 & 03 & 2.00 \\
\hline 5 & $\begin{array}{l}\text { Reduces drudgery (hand, shoulders \& Back } \\
\text { pain) }\end{array}$ & 150 & 100 & 0 & 0.00 \\
\hline 6 & It Saves times and energy & 148 & 98.66 & 02 & 1.33 \\
\hline
\end{tabular}


?

maize cultivars were big in size and could not be used during the operation. Therefore, it is suggested to developed a maize sheller which could handle the requirement of shelling different sizes of maize so that the drudgery of small and marginal farmers are solved. Similar modification of maize sheller and testing them locally had also been reported by Darudkar and Handa (2015), Rajender and Anababu (2017).

\section{CONCLUSION}

Hand held tubular maize sheller is a tool for drudgery reduction among farmers. The evidence of maximum shelling in less time compared to farmers' practice of bare hand shelling indicates that it is most suitable for the farmers', another advantage is that it operates without power source at any time with convenience. However, if shelling is to continue for long hour it can be tiresome causing drudgery also some cultivars of local varieties could not be shelled due to its larger in size. Therefore, it is suggested to modify, standardized and introduce hand operated mechanized sheller for resource poor, marginal farmers.

\section{REFERENCES}

Anonymous. 2019. Pocket book of agricultural statistics. GoI, Directorate of Economics and Statistics, New Delhi.

Anonymous. 2019a. Statistical hand book of Nagaland. Directorate of economics and statistics, Nagaland, Kohima.
Chilur, Rudragouda., Ravindra, Yaranal., Ravindra, Yaligar., Vasantgouda, B.R., Nagaraj, D.M. and Shashirekha. 2014. Pedal operated tubular maize sheller- A Novel technology for marginal and small farmers. Environment \& Ecology, 32(1A): 239-242.

Darudkar, Anirudha, G. and Handa, C.C. 2015. Literature Review of Corn Sheller Machine. International Journal for Innovative Research in Science \& Technology, 2(1): 238-240.

Imtisenla, Khekali Sema, Zhiete, Michael Pienyu, K., Temjennungsang, Longma Yanger Pongen and Akashe Zhimomi, V. 2019. Inventory of technologies in agriculture for Kohima district. Pp 24. Technical Bulletin No.-I, Krishi Vigyan Kendra, Kohima.

Karmakar, Sumit and Gouraha, A.K. 2018. Economics of Value Added Products of Maize in Chhattisgarh. International Journal of Agriculture, Environment and Biotechnology, 11(6): 889-893.

Naveenkumar, D.B. and Rajshekarappa, K.S. 2012. Performance evaluation of a power operated maize sheller. Internat. J. Agric. Engg., 5(2): 172-177.

Pandey, S., Sharma. P. and Sharma, R.K. 2013. Effectiveness of training on tubular maize sheller for reducing the drudgery of farm women. Indian Res. Jn. Ext. Educ., 13(2): 17-20.

Rajender, G. and Anababu, T. 2017. Development and performance evaluation of pedal operated maize sheller. International Journal of Agricultural Science and Research, 7(2): 547-554.

Singh, A., Gautam, U.S., Surendra. P. and Anju, S. 2010. Ergonomic evaluation of farm women during maize shelling. Indian Res. Jn. of Ext. Educ., 10(3): 41-44. 